Fish Oil의 첨가가 한우 거세우의 육성성적, 배최장근의 지방산

\author{
조성 및 도체특성에 미치는 영향 \\ 박병기* · 신종서** \\ 농촌진흥청 축산연구소*, 강원대학교 동물생명과학대학**
}

\title{
Effects of Fish Oil Supplementation on Growth Performance, Fatty Acid Composition of Longissimus Muscle and Carcass Characteristics in Hanwoo Steers
}

B. K. Park* and J. S. Shin**

National Livestock Research Institute, RDA*, College of Animal Life Sciences, Kangwon National University**

\begin{abstract}
Twenty Hanwoo steers (average body weight $=440.8 \pm 32.4 \mathrm{~kg}$ ) were used to investigate the effects of fish oil supplementation on growth performance, fatty acid composition of longissimus muscle and carcass characteristics. The experiment was done with two treatment groups; FO-0, without fish oil and FO-3, supplemented with $3 \%$ fish oil. Total gain and average daily gain (ADG) of steers were similar between two groups. Fish oil supplementation had no effects on contents of protein, ether extract and ash in longissimus muscle. Contents of isoleucine and glycine in longissimus muscle were decreased by fish oil supplementation $(p<0.05)$, but content of cystein was increased by fish oil supplementation $(p<0.05)$. Fish oil supplementation decreased contents of myristic acid and eicosenoic acid in longissimus muscle $(\mathrm{p}<0.05)$, but increased contents of oleic acid and arachidonic acid in longissimus muscle $(p<0.05)$. Contents of eicosapentaenoic acid (EPA) and docosahexaenoic acid (DHA) in longissimus muscle were increased by fish oil supplementation $\mathrm{p}<0.05$ ). Carcass weight, back fat thickness, rib-eye area, yield index and yield grade were similar between two groups. Meat color was improved by fish oil supplementation $(\mathrm{p}<0.05)$, Ratio of quality grade ' 1 or over' increased by fish oil supplementation. Therefore, the present study indicating that fish oil supplementation had positive effects on content of oleic acids in relation to flavor of beef, contents of EPA and DHA in relation to human health and ratio of quality grade ' 1 or over'.
\end{abstract}

(Key words : Hanwoo steers, Fish oil, Longissimus muscle, Fatty acid, Qaulity grade)

$$
\text { I. 서 론 }
$$

다가 불포화 지방산(polyunsaturated fatty acids; PUFA)이 인류의 건강에 미치는 영양학적 중요성 으로 인해 반추가축 특히, 쇠고기의 PUFA 함량 증진에 대한 관심이 높아지고 있다(Dannenberger 등, 2004). 특히, eicosapentaenoic acid (EPA)와 docosahexaenoic acid (DHA)의 섭취가 권장되고 있는데(Department of Health, 1994), 이들은 고 도로 불포화된 n-3 지방산의 섭취 권장량이 $0.15 \mathrm{~g} / \mathrm{d}$ 에서 $0.65 \mathrm{~g} / \mathrm{d}$ 로 4 배 정도 증가되었고 (Kris- Etherton 등, 2000), 증가된 권장량의 충족 을 위해 이들 지방산을 추가적으로 공급해야 할 필요성이 대두되고 있다(Ponnampalam 등,

Corresponding author : J. S. Shin, Division of Animal Resources Science, College of Animal Life Sciences, Kangwon National University, Chuncheon, 200-701, Korea.

Tel : 033-250-8628, Fax : 033-244-2532, E-mail : jsshin@kangwon.ac.kr. 
2001). 물론 이들 n-3 지방산의 주요 공급원은 어류이지만(Scollan 등, 2001), 어류의 소비량에 비해 지속적으로 소비량이 늘고 있는 육류 특 히, 쇠고기 섭취를 통해 이들 지방산을 공급한 다면 소비자들의 red meat에 대한 부정적인 시 각 (Dannenberger 등, 2004)과 포화지방산 함량 이 높은 쇠고기에 대한 이미지(Scollan 등, 2001)를 개선시킬 수 있을 것으로 판단된다.

물론 반추가축에서 지방산의 축적과정은 복 잡하며, 반추위에서 사료로부터 공급되는 대부 분의 중성지방이 파괴되고 지방산에 대한 biohydrogenation으로 인해(Dannenberger 등, 2004) 단위동물에 비해 조절이 어렵다. 그러나 일부 long-chain n-3 지방산들의 일정 부분은 반추위 분해를 회피하여 고기나 우유의 지방산 조성을 변화시킬 수 있으므로(Ashes 등, 1992) 사료의 지방산 조성 변경을 통해 쇠고기의 지방산 조 성 조절이 가능하며(Lorenz 등, 2002), 반추위 분해를 회피한 사료의 불포화지방산들은 근간 및 근내 지방에 침착되는 것으로 보고된 바 있 다(Wood 등, 1999). 최근까지 쇠고기 PUFA 함 량을 높이기 위한 시도는 주로 화학적 혹은 물 리적으로 변형된 오일 혹은 종실을 이용하여 linoleic acid의 공급을 통해 이루어져 왔다(Scott 과 Ashes, 1993).

한편 수산업에서 다량 발생하는 부산물들은 에너지, 단백질 등의 영양소를 공급할 수 있기 때문에 반추가축을 위한 사료자원으로서 가치가 높다(Wistuba 등, 2006). 특히, fish oil은 EPA, DHA 등과 같은 불포화지방산을 다량 함유하고 있는 우수한 지방산 공급원임에도 불구하고 최 근까지도 축우 특히, 비육우에서 폭넓게 이용 되지 못해왔다(Wistuba 등, 2006). 또한 일부 연 구들에서 fish oil의 첨가가 쇠고기의 n-3 지방 산 함량 변화에 미치는 영향만을 주로 조사하 였기 때문에 fish oil의 첨가가 비육우의 증체, 배최장근의 조성 및 도체특성에 미치는 영향에 대한 연구 결과를 찾아보기 힘든 실정이다.

따라서 본 연구는 n-3 지방산을 다량 함유하 고 있을 뿐만 아니라 다량의 에너지를 함유하고 있는 fish oil을 첨가 급여함으로서 쇠고기의 n-3 지방산 함량을 높임과 동시에 fish oil의 첨가가 한우거세우의 증체, 배최장근의 조성 및 도체특 성 변화에 미치는 영향을 구명하고 실시하였다.

\section{․ 재료 및 방법}

\section{1. 시험기간, 장소 및 공시동물}

본 시험은 2001년 7월부터 2002년 1월까지 6 개월간 강원도 홍천군 남면 소재 한우사육 농 가에서 평균체중 $440.8 \pm 32.4 \mathrm{~kg}$ 의 거세한우 20 두를 공시하여 실시하였다.

\section{2. 시험사료 제조 및 사양관리}

본 연구의 시험사료는 시판 배합사료, 발효사 료 및 볏짚을 이용하였다. 본 시험에서 fish oil 의 첨가량은 $3 \%$ 수준으로 하였으며, 균일하고 효율적인 첨가를 위해 시험사료 중에서 발효사 료의 제조과정에서 fish oil을 첨가하였다. 본 시험에서는 fish oil의 첨가로 인한 사료섭취량 의 감소를 방지하기 위해 특유의 향취를 제거 한 정제 fish oil을 이용하였다. 발효사료는 파 쇄옥수수, 맥주박, 소맥피, 루핀, 알팔파, 당밀 및 yeast를 각각 $60,19,5,4.5,4.5,5$ 및 $2 \%$ 의 비율로 혼합하여 $30^{\circ} \mathrm{C}$ 에서 48 시간 동안 발효시 켜 제조한 발효사료와 fish oil 3\%를 추가로 첨 가하여 제조한 발효사료의 2종류로 하였다. 시 험사료는 일일 2회(오전 9시 및 오후 18시) 급 여하였다. 배합사료의 급여량은 처리에 관계없 이 두당 $5 \mathrm{~kg}$ 이었고, 발효사료의 급여량은 두 당 $5 \mathrm{~kg}$ (오전 $2.5 \mathrm{~kg}$ 및 오후 $2.5 \mathrm{~kg}$ )으로 하였다. 볏짚은 3 4 cm 길이로 세절된 볏짚을 이용하 였고, 물은 항상 자유 음수토록 하였다. 시험사 료의 화학적 조성과 fish oil의 지방산 조성은 각각 Table 1 및 2와 같다.

\section{3. 시험설계}

시험구 처리는 거세 한우 20 두를 처리구당 10 두씩 완전임의 배치하였으며, 배합사료, 발효 사료 및 볏짚을 급여하는 대조구 (FO-0)와 배 합사료, fish oil 3\% 첨가 발효사료 및 볏짚을 급여하는 처리구 (FO-3)의 2처리로 하였다.

\section{4. 조사항목 및 분석방법}

증체량은 시험기간 동안 2 개월 간격으로 모 
Table 1. Chemical composition of experimental diets

\begin{tabular}{|c|c|c|c|c|}
\hline Items (\%) & Formula feed & $\mathrm{FF}^{1)}$ & FFFO $^{2)}$ & Rice straw \\
\hline \multirow[t]{2}{*}{ Dry matter } & $87.92 \pm 0.47$ & $70.57 \pm 1.12$ & $70.80 \pm 0.47$ & $83.14 \pm 2.04$ \\
\hline & $\ldots$ & ..... \% of $\mathrm{d}$ & tter $\cdots \cdots \cdots \cdots$ & ................. \\
\hline Crude protein & $12.76 \pm 0.23$ & $12.22 \pm 0.54$ & $13.47 \pm 0.30$ & $4.32 \pm 0.37$ \\
\hline Ether extract & $3.42 \pm 0.64$ & $3.52 \pm 0.10$ & $7.71 \pm 0.72$ & $2.54 \pm 0.10$ \\
\hline Crude ash & $6.76 \pm 0.30$ & $4.90 \pm 0.40$ & $3.91 \pm 0.24$ & $10.37 \pm 0.12$ \\
\hline $\mathrm{NDF}^{3)}$ & $40.46 \pm 2.88$ & $36.51 \pm 1.72$ & $31.02 \pm 0.67$ & $64.72 \pm 0.28$ \\
\hline $\mathrm{ADF}^{4)}$ & $13.55 \pm 0.72$ & $14.26 \pm 0.85$ & $13.87 \pm 0.63$ & $41.75 \pm 0.23$ \\
\hline
\end{tabular}

Table 2. Fatty acid composition of fish oil

\begin{tabular}{lc}
\hline Items & Composition (\%) \\
\hline \hline C14:0 & 9.99 \\
C16:0 & 27.96 \\
C18:0 & 6.51 \\
C16:1 & 12.40 \\
C18:1n9 & 19.52 \\
C18:2n6 & 2.32 \\
C18:3n3 & 2.30 \\
C20:4n6 & 1.55 \\
C20:5n3 & 8.75 \\
C22:6n3 & 8.70 \\
SFA & 44.46 \\
MUFA $^{2)}$ & 31.92 \\
PUFA $^{3)}$ & 23.62 \\
\hline
\end{tabular}

1) SFA : saturated fatty acid.

2) MUFA : mono-unsaturated fatty acid.

3) PUFA : poly-unsaturated fatty acid.

든 공시축들을 대상으로 우형기를 이용하여 체 중을 측정하여 계산하였다. 사료섭취량은 1 개 월 간격으로 7일 동안 연속적으로 오전 및 오 후에 사료 급여량과 잔량을 조사하여 산출하였 다. 시험 종료 후 모든 공시축들은 농협 서울 공판장으로 출하하여 도체평가는 도살 후 24시 간 냉장된 냉도체에 대한 등지방두께, 배최장 근단면적, 육량지수, 근내지방도, 육색, 지방색, 육량등급 및 육질등급 등의 항목을 도체등급판 정기준에 의거하여 축산물등급판정사가 판정하 였다. 육조성분 분석을 위한 배최장근의 채취 는 도체평가가 완료된 냉도체의 13 번째 흉추와 1 번째 요추 사이에서 채취하여 동결건조하여 분석시까지 $-20^{\circ} \mathrm{C}$ 에서 냉동 보관하였다.
배최장근의 일반화학성분은 $\mathrm{AOAC(1995)}$ 방 법에 준하여 분석하였으며, 아미노산 함량 및 조성은 Mason 등(1980)의 방법에 따라 시료를 전처리하여 HPLC(Waters 510 Pump; Waters ${ }^{\mathrm{TM}}$ Automated Gradient Controller; Waters ${ }^{\mathrm{TM}} 486$ Tunable Absorbance Detector; Waters Temperature Control Module, USA)로 분석하였다. 등심의 지 질은 Folch의 방법(Folch 등, 1957)에 준하여 chloroform-methanol(2:1) 용액으로 지질을 추출 한 후 Sukhija와 Palmquist(1988)의 방법에 따라 gas chromatography(Shimadzu Model GC-17A Ver. 3 , Japan)로 분석하였다.

\section{5. 통계분석}

본 실험에서 얻어진 성적들은 SAS package (1999)를 이용하여 분산분석 및 $\mathrm{t}$ - 검정을 실 시하여 처리구간 유의성 $(\mathrm{p}<0.05)$ 을 검증하였다.

\section{III. 결과 및 고찰}

Fish oil의 첨가로 FO-3구의 총 증체량과 일 당증체량이 FO-0구에 비해 약간 개선되는 경향 이 있었지만(p>0.05), 두 시험구간 총 증체량 및 일당증체량에 대한 통계적인 유의차이가 인 정되지 않아 fish oil의 첨가가 거세한우의 증체 에 미치는 영향이 적었다(Table 3). Fish oil의 첨가가 배합사료, 발효사료 및 볏짚 섭취량에 미치는 영향은 적었으며, 두 시험구간 사료요구 율에 대한 통계적인 유의성은 인정되지 않았지 만, fish oil의 첨가로 사료요구율이 다소 개선되 는 경향을 보였다( $>>0.05)$. 
Table 3. Effects of fish oil supplementation on growth performance and feed intake of Hanwoo steers

\begin{tabular}{lcr}
\hline Items & \multicolumn{1}{c}{ FO- $^{1)}$} & \multicolumn{1}{c}{ FO-3 $^{2)}$} \\
\hline \hline Initial wt. (kg) & $430.28 \pm 22.16$ & $451.43 \pm 23.25$ \\
Final wt. (kg) & $566.66 \pm 18.72$ & $596.51 \pm 19.23$ \\
Total body gain (kg) & $137.28 \pm 14.36$ & $145.08 \pm 11.13$ \\
$\mathrm{ADG}^{3)}(\mathrm{kg})$ & $0.88 \pm 0.05$ & $0.93 \pm 0.08$ \\
$\mathrm{DMI}^{4)}$ (kg/animal/day) & & \\
$\quad$ Formula feed & $3.58 \pm 0.62$ & $3.67 \pm 0.81$ \\
$\quad$ FF & $3.44 \pm 0.26$ & - \\
$\quad$ FFFO & - & $3.41 \pm 0.14$ \\
$\quad$ Rice straw & $1.72 \pm 0.54$ & $1.71 \pm 0.42$ \\
Feed conversion & $9.93 \pm 1.27$ & $9.45 \pm 1.19$ \\
(Feed/gain, kg/kg) &
\end{tabular}

Means in the same row did not different significantly $(\mathrm{p}>0.05)$.

${ }^{1)}$ FO-0 : formula feed + fermented feed without fish oil + rice straw.

2) FO-3 : formula feed + fermented feed supplemented with $3 \%$ fish oil+rice straw.

3) ADG : average daily gain;

4) DMI : dry matter intake.

본 연구에서 발효사료에 대한 fish oil 3\% 첨 가로 인해 일당증체량과 사료요구율이 일부 개 선되는 경향을 보이기는 하였으나, 전반적으로 fish oil의 첨가가 한우거세우의 증체와 사료섭 취량에 미치는 영향은 적은 것으로 판단된다. 일반적으로 정제 과정을 거치지 않은 fish oil은 특유의 향취로 인해 가축의 사료섭취량을 감소 시키는 특성이 있다. 물론 본 실험에서는 한우 거세우의 사료섭취량 감소를 방지하기 위해 fish oil 특유의 향취를 제거한 정제 fish oil을 사용하 였고, 발효사료의 발효과정에서 생성되는 alcohol 및 lactate와 같은 성분으로 인해 사료섭취량이 감소되지 않았던 것으로 판단되지만, fish oil의 첨가로 발효사료의 에너지 함량이 증가했음에 도 불구하고 증체의 차이가 적어 이에 대한 추 가적인 연구가 필요할 것으로 판단된다.

한편, 본 연구에서 나타난 결과는 평균체중 $441 \pm 31.7 \mathrm{~kg}$ 의 Angus 교잡종 거세우에서 fish oil $3 \%$ 첨가로 일당증체량의 차이가 없었다는 Wistube 등(2006)의 결과와는 유사한 경향을 보 였으나, 육성기 Angus 교잡종 거세우에서는 fish oil $3 \%$ 첨가로 일당증체량과 사료섭취량이 감
소되었다는 Wistuba 등(2005)의 결과와는 차이 를 보여 fish oil의 첨가가 거세우의 증체에 미 치는 영향은 비육단계에 따라 달라질 수도 있 는 것으로 판단된다. 물론 육성기 동안 fish oil 을 첨가할 경우에도 사료섭취량은 감소되지만 체내로 흡수되는 영양소의 이용성 및 증체의 개 선으로 사료효율이 향상되어(Nicholson 등, 1992) 산육능력에 미치는 부의 영향은 없는 것으로 보고하고 있다(Scollan 등, 2001). 그러나 fish oil의 첨가는 육성기 보다는 비육기가 바람직 할 것으로 판단되는데, 이는 반추위 발달을 위 해 비육기에 비해 상대적으로 조사료 공급량이 많은 육성기 동안 PUFA 함량이 높은 oil의 첨가 는 섬유소 소화율 감소와 같은 부의 영향 (Rule 등, 1989)을 미칠 가능성도 있기 때문이다.

FO-0구에 비해 FO-3구에서 배최장근의 수분 함량은 낮고 단백질 함량은 높은 경향을 보이 기는 하였으나(70.8 vs $67.9 \%$ 및 18.78 vs $20.42 \%$; $\mathrm{p}>0.05)$, 두 시험구간 배최장근의 수분, 단백질, 지방 및 회분 함량의 통계적인 유의차이가 인 정되지 않아 fish oil 첨가가 배최장근의 이들 성분 변화에 미치는 영향은 적었다(Table 4).

Wistuba 등(2006)은 Angus 교잡종 거세우를 대상으로 fish oil 3\% 첨가에 따른 배최장근의 수분, 단백질, 지방 및 회분 함량의 변화가 없었 다고 하여 본 연구와 유사한 결과를 보고하였 다. 또한 본 연구에서 예상과는 달리 fish oil 첨 가가 배최장근의 지방함량 변화에 미치는 영향 은 없었는데, 사료의 지방함량 증가와 도체의 지방함량 증가간에 항상 비례적인 관계가 있는 것은 아니라는 Rule 등(1994)의 연구결과와 fish oil 혹은 fish meal의 첨가가 도체의 지방함량에 영향을 미치지 않았다는 이전의 연구결과들 (Scollan 등, 2001; Mandell 등, 1997; Comerford

Table 4. Effects of fish oil supplementation on chemical composition in longissmus muscle of Hanwoo steers

\begin{tabular}{lrr}
\hline Items (\%) & \multicolumn{1}{c}{ FO-0 } & \multicolumn{1}{c}{ FO-3 } \\
\hline \hline Moisture & $70.8 \pm 1.06$ & $67.9 \pm 0.74$ \\
Crude protein & $18.78 \pm 0.71$ & $20.42 \pm 0.59$ \\
Ether extract & $8.14 \pm 0.58$ & $8.75 \pm 0.57$ \\
Ash & $0.95 \pm 0.07$ & $0.91 \pm 0.16$ \\
\hline
\end{tabular}

Means in the same row did not different significantly $(\mathrm{p}>0.05)$ 
Table 5. Effects of fish oil supplementation on amino acid composition in longissimus muscle of Hanwoo steers

\begin{tabular}{lcc}
\hline Items (\%) & FO-0 & FO-3 \\
\hline \hline Arginine & $6.32 \pm 0.41$ & $6.41 \pm 0.87$ \\
Histidine & $6.55 \pm 0.52$ & $6.45 \pm 1.16$ \\
Isoleucine & $5.20 \pm 0.28^{\mathrm{a}}$ & $4.79 \pm 0.74^{\mathrm{b}}$ \\
Leucine & $8.65 \pm 0.46$ & $8.89 \pm 1.57$ \\
Lysine & $9.33 \pm 0.61$ & $9.03 \pm 1.76$ \\
Methionine & $2.75 \pm 0.16$ & $3.13 \pm 0.62$ \\
Phenylalanine & $4.24 \pm 0.32$ & $4.30 \pm 0.73$ \\
Threonine & $5.34 \pm 0.34$ & $5.29 \pm 0.98$ \\
Valine & $5.15 \pm 0.28$ & $5.26 \pm 0.95$ \\
Alanine & $6.27 \pm 0.40$ & $6.14 \pm 1.05$ \\
Aspartic acid & $7.14 \pm 1.52$ & $7.54 \pm 2.19$ \\
Cystein & $0.44 \pm 0.06^{\mathrm{b}}$ & $0.64 \pm 0.18^{\mathrm{a}}$ \\
Glutamic acid & $16.36 \pm 1.20$ & $15.57 \pm 3.48$ \\
Glycine & $5.05 \pm 0.59^{\mathrm{a}}$ & $4.49 \pm 0.74^{\mathrm{b}}$ \\
Proline & $4.15 \pm 0.41$ & $4.24 \pm 0.81$ \\
Serine & $3.80 \pm 0.37$ & $4.30 \pm 0.88$ \\
Tyrosine & $3.27 \pm 0.20$ & $3.62 \pm 0.63$ \\
EAA $^{1)}$ & $53.21 \pm 0.37$ & $53.47 \pm 1.04$ \\
NEAA $^{2)}$ & $46.49 \pm 0.59$ & $46.53 \pm 1.24$ \\
\hline
\end{tabular}

a,b Means with different superscripts in the same row differ significantly $(\mathrm{p}<0.05)$.

1) EAA : essential amino acid.

2) NEAA : nonessential amino acid.

등, 1992)과 유사한 경향을 보였던 것으로 판단 된다. 따라서 fish oil의 첨가는 한우거세우 배최 장근의 단백질, 지방 등의 성분 변화보다는 배 최장근의 지방을 구성하는 지방산조성 변화에 선택적으로 관여하는 것으로 판단된다(Table 6). 한우거세우 배최장근에서 분석한 아미노산 중 에서 isoleucine 및 glycine 함량은 FO-3구가 FO-0 구에 비해 낮았으나(4.79 vs $5.20 \%$ 및 4.49 vs $5.05 \%$; $<<0.05$; Table 5), cystein 함량은 FO-3구가 FO-0구에 비해 높았다(0.64 vs $0.44 \% ; \mathrm{p}<0.05)$. 그 러나 배최장근의 총 필수 및 비필수 아미노산 함량의 경우 fish oil 첨가의 영향은 없었다. 이 상의 결과에서 fish oil의 첨가는 배최장근의 아 미노산 중에서 cystein과 glycine 함량 변화에 일 부 영향을 미쳤으나, fish oil의 첨가가 거세한우 배최장근의 전반적인 아미노산 조성에 대한 영 향이 적은 것으로 판단된다. 따라서 fish oil의
첨가로 한우거세우 배최장근의 단백질 함량 (Table 4)과 아미노산 함량 변화에 영향은 적어 fish oil의 첨가가 거세한우의 체내 단백질 대사 에 미치는 영향은 낮은 것으로 판단된다.

한우거세우 배최장근의 myristic $\operatorname{acid}(\mathrm{C} 14: 0)$ 및 eicosenoic acid(C20:1n9) 함량은 FO-3구가 FO-0구에 비해 낮았다(0.68 vs $2.17 \%$ 및 0.26 vs $0.69 \%$; $<<0.05$; Table 6). 한편 oleic acid(C18:1n9) 및 arachidonic acid(C20:4n6) 함량은 FO-3구가 FO-0구에 비해 높았다(49.98 vs 43.65\% 및 0.09 vs $0.04 \% ; \mathrm{p}<0.05)$. 또한 $\mathrm{EPA}(\mathrm{C} 20: 5 \mathrm{n} 3)$ 및 $\mathrm{DHA}$ (C22:6n3) 함량도 FO-3구가 FO-0구에 비해 높 았다(0.20 vs $0.13 \%$ 및 0.07 vs $0.02 \%$; $<<0.05$ ). 한편 배최장근의 총 포화지방산, 단일 불포화 지방산 및 다가 불포화 지방산 함량은 $\mathrm{FO}-0$ 구 와 FO-3구간에 통계적인 유의성은 없었지만, FO-0구에 비해 FO-3구에서 포화지방산 함량은 낮은(47.16 vs 42.68\%) 경향이었고, 단일 불포화 지방산 및 다가 불포화지방산 함량은 높은(50.41 vs $54.26 \%$ 및 2.43 vs $3.06 \%)$ 경향이었다.

Table 6. Effects of fish oil supplementation on fatty acid composition in longissimus muscle of Hanwoo steers

\begin{tabular}{lcc}
\hline Items (\%) & FO-0 & FO-3 \\
\hline \hline C14:0 & $2.17 \pm 0.04^{\mathrm{a}}$ & $0.68 \pm 0.10^{\mathrm{b}}$ \\
C16:0 & $34.94 \pm 0.69$ & $30.57 \pm 0.80$ \\
C18:0 & $10.06 \pm 0.30$ & $11.42 \pm 0.87$ \\
C16:1 & $6.07 \pm 0.24$ & $4.02 \pm 0.20$ \\
C18:1n9 & $43.65 \pm 0.22^{\mathrm{b}}$ & $49.98 \pm 1.07^{\mathrm{a}}$ \\
C20:1n9 & $0.69 \pm 0.02^{\mathrm{a}}$ & $0.26 \pm 0.02^{\mathrm{b}}$ \\
C18:2n6 & $2.06 \pm 0.05$ & $2.38 \pm 0.15$ \\
C18:3n3 & $0.15 \pm 0.01$ & $0.13 \pm 0.01$ \\
C20:4n6 & $0.04 \pm 0.01^{\mathrm{b}}$ & $0.09 \pm 0.01^{\mathrm{a}}$ \\
C20:5n3 & $0.13 \pm 0.01^{\mathrm{b}}$ & $0.20 \pm 0.02^{\mathrm{a}}$ \\
C22:4n6 & $0.04 \pm 0.00$ & $0.18 \pm 0.04$ \\
C22:6n3 $_{\text {SFA }^{1)}}^{0.02 \pm 0.00^{\mathrm{b}}}$ & $0.07 \pm 0.01^{\mathrm{a}}$ \\
MUFA $^{2)}$ & $47.16 \pm 0.34$ & $42.68 \pm 0.59$ \\
PUFA $^{3)}$ & $50.41 \pm 0.16$ & $54.26 \pm 0.43$ \\
\hline
\end{tabular}

\footnotetext{
${ }^{a, b}$ Means with different superscripts in the same row differ significantly $(\mathrm{p}<0.05)$.

1) SFA : saturated fatty acid.

2) MUFA : mono-unsaturated fatty acid.

3) PUFA : poly-unsaturated fatty acid.
} 
Sturdivant 등 (1992)은 쇠고기의 지방산 조성 은 소비자의 기호성에 영향을 미치는데, 특히 myristic acid나 palmitic acid와 같은 포화지방산 함량은 배최장근의 다즙성과 부 $(-)$ 의 관계에 있다고 하였는데, 본 연구에서 fish oil 첨가는 myristic acid 함량은 감소시키고 palmitic acid 함량도 감소시키는 경향을 보여 배최장근의 다 즙성 변화에도 영향을 미칠 수 있는 것으로 판 단된다.

한편, 본 연구에서는 fish oil 첨가로 인해 stearic acid(C18:0) 함량은 변화가 없었으나 oleic acid 와 arachidonic acid 함량이 증가되었는데, fish meal 첨가시 도체의 stearic acid 함량이 감소 되었다는 결과들(Mandell 등, 1997; Mills 등, 1992) 및 fish oil 첨가로 인한 근육의 인지질 내 arachidonic acid의 함량 변화가 없었다는 Mandell 등 (1997)의 결과와는 차이가 있었다. 그러나 fish oil의 첨가는 고기의 풍미와 조직감 을 향상시켜 관능검사에서 긍정적인 결과를 얻 게 하는 oleic acid 함량 (Sturdivant 등, 1992)을 개선시키는 것으로 판단된다.

본 연구에서는 fish oil 첨가로 배최장근의 $\mathrm{EPA}$ 와 $\mathrm{DHA}$ 함량이 2 배 이상 증가되었는데, $\mathrm{EPA}$ 혹은 DHA와 같은 일부 long-chain n-3 지 방산들의 일정 부분이 반추위 분해를 회피하여 쇠고기의 지방산 조성을 변화시킨다는 Ashes 등(1992)의 결과와 유사한 경향을 보인 것으로 판단된다. 또한 비육우 사료에 대한 fish oil 첨 가로 도체의 지방산 중 $\mathrm{EPA}$ 와 $\mathrm{DHA}$ 함량이 2 배 이상 증가하였다는 연구결과들 (Bourre, 2005; Scollan 등, 2001)과 일치하여 fish oil의 첨가가 쇠고기의 이들 지방산 함량 증가에 효 과적인 것으로 판단된다. 그러나 fish oil의 첨 가로 배최장근의 지방산 중 일부 지방산 함량 변화로 SFA 함량은 감소하고 MUFA 및 PUFA 함량은 증가하는 경향을 보이기는 하였으나, 두 시험구의 SFA, MUFA 및 PUFA 함량간 유의적 인 차이가 없어 fish meal의 첨가가 배최장근의 MUFA 함량 변화에 대한 영향은 적었다는 Mandell 등 (1997)의 결과와 유사한 경향으로 나타났다.

따라서 본 연구의 결과에서 fish oil의 첨가는 배최장근의 지방산 중 다즙성에 부의 영향을 미 치는 myristic acid와 palmitic acid 함량은 감소시
Table 7. Effects of fish oil supplementation on carcass characteristics of Hanwoo steers

\begin{tabular}{lcc}
\hline Items & FO-0 & FO-3 \\
\hline \hline Yield traits & & \\
Carcass weight $(\mathrm{kg})$ & $324.58 \pm 16.43$ & $350.43 \pm 20.30$ \\
Back fat thickness (mm) & $6.50 \pm 2.63$ & $9.40 \pm 5.62$ \\
Rib-eye area $\left(\mathrm{cm}^{2}\right)$ & $76.83 \pm 4.74$ & $81.65 \pm 6.02$ \\
Yield index & $69.45 \pm 1.09$ & $68.53 \pm 2.23$ \\
Yield grade (A:B:C) & $7: 3: 0$ & $6: 3: 1$ \\
Quality traits & & \\
Marbling score & $3.17 \pm 1.34$ & $3.75 \pm 1.64$ \\
Meat color & $5.00 \pm 0.00^{\mathrm{a}}$ & $4.50 \pm 0.50^{\mathrm{b}}$ \\
Fat color & $2.67 \pm 0.47$ & $2.75 \pm 0.43$ \\
Quality grade $\left(1^{+}: 1: 2: 3\right)$ & $0: 3: 7: 0$ & $3: 2: 4: 1$ \\
\hline a,b Means with different superscripts in the same row \\
\multicolumn{2}{l}{ differ significantly(p<0.05). }
\end{tabular}

키는 반면에 풍미와 조직감을 개선하는 oleic acid 함량을 증진시켜 한우거세우 배최장근의 기호성과 풍미를 높여주는 것으로 판단된다. 또 한 DHA와 EPA와 같은 n-3 PUFA는 두뇌 발달, 심장혈관 질환 예방 및 치매 예방 기능 (Bourre, 2005) 이외에도 소염작용 등과 같은 면역력 증 진(Gerster, 1995; Calder, 1997)에도 관여하는데, 본 연구에서 fish oil의 첨가로 이들 지방산 함 량이 증가한 결과는 인체에 유익한 기능성 쇠 고기 생산의 측면에서도 큰 의미가 있음을 시 사하고 있다.

도체의 육량형질인 도체중, 등지방두께, 배최 장근단면적 및 육량지수는 $\mathrm{FO}-0$ 구와 $\mathrm{FO}-3$ 구간 에 현저한 차이는 없었지만, $\mathrm{FO}-0$ 구에 비해 FO-3구에서 fish oil의 첨가로 인해 등지방 두께 $(6.50$ vs $9.40 \mathrm{~mm})$ 와 배최장근단면적 $(76.83$ vs $81.65 \mathrm{~cm}^{2}$ )이 다소 증가하는 경향을 보였다 (Table 7). 한편 육량등급은 FO-0구가 FO-3구에 비해 A 등급 출현 두수가 1 두 많았다(7 vs 6 두).

한편, 육질형질 중 육색은 $\mathrm{FO}-0$ 구에 비해 FO-3구에서 옅어졌다(5.00 vs 4.50; $\mathrm{p}<0.05)$. 그러 나 지방색은 fish oil의 첨가에 의한 영향이 없었 다. 한편 육질등급은 FO-3구가 FO-0구에 비해 1 등급 이상 출현두수가 2 두 많았다(5 vs 3 두).

본 연구의 결과에서 fish oil의 첨가가 거세한 우의 육량형질에 미치는 영향은 없었는데, fish oil 첨가가 비육우의 도체중에 영향을 미치지 
않았다는 Scollan 등(2001)의 연구와 거세우의 배최장근단면적, 등지방두께 및 육량 등급에 영향을 미치지 않았다는 Wistube 등(2006)의 연 구 결과와 유사한 경향을 보였으나, 본 연구에 서는 fish oil의 첨가로 등지방두께와 배최장근 단면적이 약간 증가하는 경향이 있어 이전의 연구결과들과 부분적인 차이가 있는 것으로 나 타났다.

한편, Wistuba 등(2006)은 fish oil의 첨가가 거 세우의 육색, 근내지방도 및 육질등급에 미치는 영향은 없었다고 보고하고 있는데, 본 연구의 결과에서는 비록 유의적인 차이는 없었지만, fish oil의 첨가로 근내지방도와 육질 1 등급 이 상 출현두수가 증가하는 경향을 보였을 뿐만 아니라 육색의 경우에는 옅어지는 결과를 보여 이전의 연구결과들과는 다소 차이를 보인 것으 로 사료된다.

따라서 본 연구의 결과에서 fish oil의 첨가는 한우거세우의 증체나 배최장근의 조성에 대한 영향 보다는 쇠고기의 지방산 중에서 풍미와 조직감에 관여하는 oleic acid 함량과 인체에 유 익한 $\mathrm{EPA}$ 및 $\mathrm{DHA}$ 함량을 증가시켜 줄 뿐만 아니라 육질 1 등급 이상 출현두수를 증가시키 는 것으로 판단된다.

$$
\text { IV. 요 약 }
$$

본 연구는 fish oil의 첨가가 한우거세우의 증 체, 배최장근의 지방산 조성 및 도체등급에 미 치는 영향을 구명하고자 평균체중 $440.8 \pm 32.4$ $\mathrm{kg}$ 의 한우거세우 20 두를 공시하여 실시하였다. 시험구 배치는 fish oil을 첨가하지 않는 FO-0구 와 fish oil을 3\% 첨가하는 $\mathrm{FO}-3$ 구의 2처리로 하였다. 총 증체량과 일당증체량은 fish oil의 첨 가에 관계없이 비슷한 결과를 보였다. Fish oil 의 첨가는 배최장근의 단백질, 지방 및 회분 함량 에 영향을 미치지 않았다. 배최장근의 isoleucine 및 glycine 함량은 fish oil의 첨가로 감소되었으 나 $(\mathrm{p}<0.05)$, cystein 함량은 증가되었다 $(\mathrm{p}<0.05)$. Fish oil의 첨가는 배최장근의 myristic acid 및 eicosenoic acid 함량은 감소시켰으나 $(\mathrm{p}<0.05)$, oleic acid 및 arachidonic acid 함량은 증가시켰다 $(\mathrm{p}<0.05)$. 또한 배최장근의 $\mathrm{EPA}$ 및 $\mathrm{DHA}$ 함량 은 fish oil의 첨가로 증가되었다 $(\mathrm{p}<0.05)$. 도체
중, 등지방두께, 배최장근단면적, 육량지수 및 육량등급은 fish oil의 첨가에 관계없이 두 처 리구간에 유사한 경향을 보였다. 육색은 fish oil의 첨가로 개선되었으며 $(\mathrm{p}<0.05)$, 육질 1 등 급 이상 출현두수는 fish oil의 첨가로 증가하는 결과를 보였다. 따라서 본 연구의 결과에서 한 우거세우에 대한 fish oil의 첨가는 쇠고기의 지 방산 중에서 풍미 및 기호성에 관여하는 oleic acid 함량, 인간의 건강과 관련이 있는 EPA 및 $\mathrm{DHA}$ 함량 및 육질 1 등급 이상 출현두수를 증 가시키는데 효과적인 것으로 나타났다.

$$
\mathrm{V} \text {. 사 사 }
$$

본 연구는 강원대학교 동물자원공동연구소의 실험기자재를 이용하여 실험분석을 하였기에 이에 감사드립니다.

\section{$\mathrm{VI}$. 인 용 문 헌}

1. AOAC. 1995. Official Methods of Analysis. 16th Ed. Association of Official Analytical Chemist, Washington D.C., U.S.A.

2. Ashes, J. R., Siebert, B. D., Gulati, S. K., Cuthbertson, A. Z. and Scott, T. W. 1992. Incorporation of n-3 fatty acids of fish oil into tissue and serum lipids of ruminants. Lipids. 27:629-631.

3. Bourre, J. M. 2005. Where to find omega-3 fatty acids and how feeding animals with diet enriched in omega-3 fatty acids to increase nutritional value of derived products for human: what is actually useful? J. Nutr. Health Aging. 9:232-242.

4. Calder, P. C. 1997. n-3 Polyunsaturated fatty acids and cytokine production in health and disease. Ann. Nutr. Met. 41:203-234.

5. Comerford, J. W., House, R. B., Harpster, H. W., Henning, W. R. and Cooper, J. B. 1992. Effects of forage and protein source on feedlot performance and carcass traits of Holstein and crossbred beef steers. J. Anim. Sci. 70:1022-1031.

6. Dannenberger, D., Nuernberg, G., Scollan, N., Schabbel, W., Steinhart H., Ender K. and Nuernberg, K. 2004. Effect of diet on the deposition of n-3 fatty acids, conjugated linoleic and C18:1trans fatty acid 
isomers in muscle lipids of German Holstein bulls. J. Agric. Food Chem. 52:6607-6615.

7. Department of health. 1994. Report on health and social subjects No. 46. Nutritional aspects of cardiovascular disease. London: HMSO.

8. Folch, J., Lees, M. and Stanley, G. H. S. 1957. A simple method for the isolation and purification of total lipid from animal tissues. J. Biol. Chem. 226:497-509.

9. Gerster, H. 1995. The use of n-3 PUFAs (fish oil) in enteral nutrition. Int. J. Vit. Nutr. Res. 65:3-20.

10. Kris-Etherton, P. M., Taylor, D. S., Yu-Poth, S., Huth, P., Moriarty, K., Fishell, V., Hargrove, R. L., Zhao, G. and Etherton, T. D. 2000. Polyunsaturated fatty acids in the food chain in the United States. Am. J. Clin. Nutr. 71(Suppl.):179S.

11. Lorenz, S., Buettner, A., Ender, K., Nuernberg, G., Papstein, H. J., Schieberle, P. and Nuernberg, K. 2002. Influence of keeping system on fatty acid composition in the longissimus muscle of bulls and odorants formed after pressuer-cooking Eur. Food Res. Technol. 214:112-118.

12. Mandell, I. B., Buchanan-Smith, J. G., Holub, B. J. and Campbell, C. P. 1997. Effects of fish meal in beef cattle diets on growth performance, carcass characteristics, and fatty acid composition of longissimus muscle. J. Anim. Sci. 75:910-919.

13. Mason, V. C., Bach, A. S. and Rudeom, M. 1980. Hydrolysate preparation for amino acids determinations in feed constituents. 3rd EAAP- Symposium on protein metabolism and nutrition. Braunchweig.

14. Mills, E. W., Comerford, J. W., Hollender, R., Harpster, H. W., House, B. and Henning, W. R. 1992. Meat composition and palatability of Holstein and beef steers as influenced by forage type and protein source. J. Anim. Sci. 70:2446-2451.

15. Nicholson, J. W., Charmeley, G. E. and Bush, R. S. 1992. The effect of supplemental protein source on ammonia levels in rumen fluid and blood and intake of alfalfa silage by beef cattle. Can. J. Anim. Sci. 72:853-862.

16. Ponnampalam, E. N., Trout, G. R., Sinclair, A. J., Egan, A. R. and Leury, B. J. 2001. Comparison of the color stability and lipid oxidative stability of fresh and vacuum packaged lamb muscle containing elevated omega-3 and omega-6 fatty acid levels from dietary manipulation. Meat Sci. 58:151-161.

17. Rule, D. C., Busboom, J. R. and Kercher, C. J. 1994. Effect of dietary canola on fatty acid composition of bovine adipose tissue, muscle, kidney, and liver, J. Anim. Sci. 72:2735-2744.

18. Rule, D. C., Wu, W. H., Busboom, J. R., Hinds, F. C. and Kercher, C. J. 1989. Dietary canola seeds alter the fatty acid composition of bovine subcutaneous adipose tissue, Nutr. Rep. Int. 39:781-786.

19. SAS. 1999. SAS/STAT Software for PC. Release 6.11, SAS Institute, Cary, NC, U.S.A.

20. Scollan, N. D., Choi, N., Kurt, E., Fisher, A. V., Enser, M. and Wood, J. D. 2001. Manipulating the fatty acid composition of muscle and adipose tissue in beef cattle. Br. J. Nutr. 85:115-124.

21. Scott, T. W. and Ashes, J. R. 1993. Dietary lipids for ruminants: protection, utilization and effects on remodeling of skeletal muscle phospholipids. Australian J. Agric. Res. 44:495-508.

22. Sturdivant, C. A., Lunt, D. K., Smith, G. C. and Smith, S. B. 1992. Fatty acid composition of subcutaneous and intramuscular adipose tissues and M. longissimus dorsi of Wagyu cattle. Meat Sci. 32:449-458.

23. Sukhija, P. S. and Palmquist, D. L. 1988. Rapid method for determination of total fatty acid content and composition of feedstuffs and feces. J. Agric. Food Chem. 36:1202-1206.

24. Wistuba, T. J., Kegley, E. B. and Apple, J. K. 2006. Influence of fish oil in finishing diets on growth performance, carcass characteristics, and sensory evaluation of cattle. J. Anim. Sci. 84:902-909.

25. Wistuba, T. J., Kegley, E. B., Apple, J. K. and Davis, M. E. 2005. Influence of fish oil supplementation on growth and immune system characteristics of cattle. J. Anim. Sci. 83:1097-1101.

26. Wood, J. D., Enser, M., Fisher, A. V., Nute, G. R., Richardson, R. I. and Sheard, P. R. 1999. Manipulating meat quality and composition. Proc. Nutr. Soc. 58:363-370.

(접수일자 : 2006. 11. 6. / 채택일자 : 2007. 1. 29.) 